\title{
SURVEY OF PUBLIC SWIMMING POOLS IN THE MID WESTERN AREA HEALTH SERVICE: 2000-2001
}

\section{Jason Thorne}

Trainee Environmental Health Officer

Mid Western Public Health Unit

This article describes a survey conducted by the Mid Western Public Health Unit to identify potential risks to the public health presented by public swimming pools within the geographical area covered by the Mid Western Area Health Service (MWAHS) during the 2000-2001 swimming season.

\section{BACKGROUND}

Public swimming pools are well-recognised sources of infection. For example, external otitis media is 2.3 times more likely to occur in swimmers than non-swimmers. ${ }^{1}$ Disease-causing organisms can be introduced from many sources but are mainly associated with bathers (see Box below).

MICROORGANISMS THAT CAN BE INTRODUCED
TO SWIMMING POOLS BY BATHERS
Bacteria
P. aeruginosa associated with eye, ear and skin
infections;
Coagulase positive staphylococci associated with
skin infections such as boils, carbuncles and wound
infections; ${ }^{2}$
Fungi
Trichophyton mentagophytes, which causes athletes
foot and tinea pedis;
Candida albicans, which can cause urino-genital, skin
and nail infections; ${ }^{2}$
Viruses
Enteroviruses, which can cause gastroenteritis;
Adenoviruses types 3 and 4, which can cause
pharyngo-conjunctival fever;
Protozoa
Cryptosporidium parvum, which can cause
Cryptosporidiosis;
Giardia lambia, which can cause Giardiasis. ${ }^{2}$

These organisms can reside in a bather's skin, saliva, urine, or faeces and can be transmitted to fellow bathers if they are not killed quickly and effectively through disinfection. Some of these disease-causing organisms can live and grow in pool water unless the pool is properly and continuously disinfected. ${ }^{2,3}$

To combat the potential health risks associated with public swimming and spa pools, the Public Swimming Pool and Spa Pool Guidelines 1996 were developed by the NSW Department of Health. ${ }^{2}$ The Guidelines specify minimum levels of chemicals and disinfectants for treating the water of public swimming and spa pools. The Guidelines were specifically drafted for application in:

- municipal swimming pools and spa pools;

- pools in hotels and motels, clubs, schools, gymnasiums and health resorts, squash and tennis centres, recreational resorts, hospitals (hydrotherapy pools), workplaces, and places of entertainment.

The Guidelines were not intended to apply to private residential premises (such as single and dual occupancy premises, flats, strata title residential premises, or retirement villages). ${ }^{2}$

\section{AIM AND OBJECTIVES OFTHE PUBLIC SWIMMING POOLS SURVEY}

The aim of the public swimming pools survey was to determine the overall compliance rates of public swimming pool operators with a number of chemical parameters for water quality in accordance with the Public Swimming and Spa Pool Guidelines 1996. ${ }^{2}$ The objectives of the survey were to determine:

- the number of public swimming pools that satisfy the requirements of the Guidelines;

- whether pool operators are familiar with and using the Guidelines;

- the location of pools for future surveys.

\section{METHODOLOGY}

Thirty-six of 42 local government operated public swimming pools were surveyed. To determine the compliance rate, and to test water quality, the parameters used for testing were based on those set out in the Guidelines. Olympic, 25-metre, and toddler pools were surveyed between December 2000-January 2001.

Water samples from the Olympic pools were analysed with a Palintest-Pooltest 25 Interface Photometer, ${ }^{4}$ and samples from the toddler pools were analysed using a PalintestPhotometer $5000,{ }^{5}$ following the procedures set out in each instruction booklet. ${ }^{4,5}$ The two test kits used were not calibrated against each other.

The following explains the parameters tested, the Guideline level required, and the test method used for each parameter:

- chlorine: the disinfectant form of chlorine is 'free chlorine'. This term refers to the concentration of hypochlorous acid and the hypochlorite ion in equilibrium concentration in the pool water. It is safe when used properly and is still the most popular form of disinfection. It is recommended that all of the chlorine is available as free chlorine. ${ }^{2}$ The test for 
chlorine used was the diethyl-p-phenylene diamine suplhate (DPD) method by Palintest; ${ }^{4,5}$

- $\mathbf{p H}$ : the higher the $\mathrm{pH}$ above 7 the less the disinfecting power of free chlorine. The $\mathrm{pH}$ needs to be controlled in swimming and spa pools when chlorine is used and automatic adjustment is recommended to levels between 7.2-7.8. ${ }^{2}$ The test used for $\mathrm{pH}$ was the phenol indicator method by Palintest; 4 ,5

- reserve alkalinity: reserve alkalinity_if not within the required limit of the 1996 Guidelines-can affect the $\mathrm{pH}$ level, which in turn affects the disinfection power of free chlorine. ${ }^{6}$ Total alkalinity is an important test in determining the scale forming tendency of the water. If the total alkalinity is low the water may cause corrosion to pipework and structures; if the total alkalinity is high the water may more readily promote scale formation. Alkalinity control is therefore an important part of many water treatment programs. ${ }^{4,5}$ The test used for reserve alkalinity was the alkaphot method by Palintest; ${ }^{4,5}$
- cyanurate: chlorinated isocyanurate and isocyanuric acid are used to stabilise chlorine against losses due to ultra violet light in direct sunlight. Chlorinated isocyanurates provide free chlorine when dissolved in water. All isocyanurated chlorine compounds (except sodium dichloroisocyanurate) tend to lower the $\mathrm{pH}$ by varying amounts when added to water. ${ }^{2}$ Research on outdoor pools has shown that, on a sunny day, free chlorine without isocyanuric acid had lost 90 per cent of the free chlorine within three hours. Pools containing 25 to $50 \mathrm{mg} / \mathrm{L}$ of isocyanuric acid under the same conditions only lost around 15 per cent of free chlorine. No appreciable increase in chlorine stability occurred above $50 \mathrm{mg} / \mathrm{L}$. The test for cyanurate was the diethyl-p-phenylene diamine suplhate (DPD) method by Palintest. ${ }^{4,5}$

Table 1 sets out the requirements of each of the chemical requirements of the above parameters.

\section{TABLE 1}

CHEMICAL REQUIREMENTS FOR CHLORINATED PUBLIC SWIMMING POOLS

\begin{tabular}{|c|c|c|c|c|c|}
\hline Pool Type & $\begin{array}{c}\text { Chemical } \\
\text { Free Chlorine } \\
\text { (mg/L) } \\
\text { minimum }\end{array}$ & $\begin{array}{l}\text { Parameters for } \\
\text { Total Chlorine } \\
\text { (mg/L) } \\
\text { maximum }\end{array}$ & $\begin{array}{l}\text { ol Type } \\
\text { Combined } \\
\text { chlorine } \\
\text { (mg/L) } \\
\text { maximum }\end{array}$ & pH Range & $\begin{array}{c}\text { Total } \\
\text { Alkalinity } \\
(\mathrm{mg} / \mathrm{L}) \text { range }\end{array}$ \\
\hline Outdoor & 1.0 & 10.0 & 1.0 & $7.2-7.8$ & $80-200$ \\
\hline Outdoor stabilised with isocyanuric acid & 3.0 & 10.0 & Not Applicable & $7.2-7.8$ & $80-200$ \\
\hline Indoor-temperature $\leq 26^{\circ} \mathrm{C}$ & 1.5 & 10.0 & 1.0 & $7.2-7.8$ & $80-200$ \\
\hline Indoor-temperature $>26^{\circ} \mathrm{C}$ & 2.0 & 10.0 & 1.0 & $7.2-7.8$ & $80-200$ \\
\hline
\end{tabular}

\section{TABLE 2}

PERCENTAGE OF POOLS FAILING EACH CHEMICAL PARAMETER 2000-2001

\begin{tabular}{|c|c|c|c|c|c|c|c|c|}
\hline Pool Type & $\begin{array}{l}\text { Number } \\
\text { of pools }\end{array}$ & $\begin{array}{l}\text { Number } \\
\text { surveyed }\end{array}$ & $\begin{array}{c}\text { Free } \\
\text { chlorine } \\
>1 \mathrm{mg} / \mathrm{L}\end{array}$ & $\begin{array}{c}\text { Total } \\
\text { chlorine } \\
<10 \mathrm{mg} / \mathrm{L}\end{array}$ & $\begin{array}{l}\text { Combined } \\
\text { chlorine } \\
<1 \mathrm{mg} / \mathrm{L}\end{array}$ & $\begin{array}{c}\mathrm{pH} \\
7.2-7.8\end{array}$ & $\begin{array}{c}\text { Reserve } \\
\text { alkalinity } \\
\text { 80-200mg/ L }\end{array}$ & $\begin{array}{l}\text { Cyanurate } \\
25-50 \mathrm{mg} / \mathrm{L}\end{array}$ \\
\hline 50m Olympic & 14 & 14 & 21 & 14 & 0 & 29 & 36 & 36 \\
\hline $25 \mathrm{~m}$ & 13 & 11 & 7 & 7 & 0 & 20 & 40 & 33 \\
\hline Toddler & 15 & 11 & 25 & 17 & 0 & 17 & 17 & 25 \\
\hline Total & 42 & 36 & & & & & & \\
\hline
\end{tabular}

\section{TABLE 3}

PERCENTAGE OF POOLS FAILING EACH CHEMICAL PARAMETER 1992-1993

\begin{tabular}{|c|c|c|c|c|c|c|c|c|}
\hline Pool Type & $\begin{array}{l}\text { Number } \\
\text { of pools }\end{array}$ & $\begin{array}{l}\text { Number } \\
\text { surveyed }\end{array}$ & $\begin{array}{c}\text { Free } \\
\text { chlorine } \\
>1 \mathrm{mg} / \mathrm{L}\end{array}$ & $\begin{array}{c}\text { Total } \\
\text { chlorine } \\
<10 \mathrm{mg} / \mathrm{L}\end{array}$ & $\begin{array}{l}\text { Combined } \\
\text { chlorine } \\
<1 \mathrm{mg} / \mathrm{L}\end{array}$ & $\begin{array}{c}\mathrm{pH} \\
7.2-7.8\end{array}$ & $\begin{array}{c}\text { Reserve } \\
\text { alkalinity } \\
\text { 80-200mg/ L }\end{array}$ & $\begin{array}{l}\text { Cyanurate } \\
25-50 \mathrm{mg} / \mathrm{L}\end{array}$ \\
\hline 50m Olympic & 14 & 14 & 21 & 7 & 0 & 21 & 36 & 43 \\
\hline $25 \mathrm{~m}$ & 13 & 13 & 52 & 46 & 8 & 31 & 15 & 8 \\
\hline Toddler & 15 & 15 & 20 & 13 & 0 & 13 & 20 & 61 \\
\hline Total & 42 & 42 & & & & & & \\
\hline
\end{tabular}


The results of the 2000-2001 survey were compared to the results of a 1992-1993 survey for local government operated swimming pools in the MWAHS.

\section{RESULTS}

Table 2 shows the percentage of pools failing each chemical parameter in 2000-2001. Table 3 shows the results for the 1992-1993. Table 4 shows the overall failure rate for pools in both surveys. The failure rate is expressed as a percentage, which was calculated by dividing the number of failures by the number of samples that were taken for each parameter.

A pool failed testing if one or more of the chemical parameters for the pool did not meet the requirements of the 1996 Guidelines. The overall failure rate for the pools surveyed in 2000-2001 was 69 per cent as compared to the 71 per cent for the 1992-1993 survey, indicating similar failure rates in both surveys. The high overall failure rate in the 2000-2001 survey can be attributed to the high percentage of cyanurate and reserve alkalinity failures.

As can be seen from the tables, there were improvements in three of the seven parameters for 2000-2001, notably in free chlorine and cyanurate. Free chlorine improved by 19 per cent and cyanurate had a 15 per cent improvement.

\section{DISCUSSION}

Although the majority of public swimming pools failed to meet the minimum chemical levels for parameters set out in the Guidelines, the risk to public health should not be overstated given that chlorine levels are the primary indication of public health risk. In spite of this, like the 1992-1993 survey, the results for the MWAHS public swimming pools survey are disappointing. The high overall failure rates can be attributed to pool operators' maintaining the minimum chemical levels for parameters set out in the Guidelines, which do not allow for external influences that affect those chemical parameters. ${ }^{6}$ Bather load, type of dosing, weather and temperature can all have a bearing on what the levels of each parameter are and how easy or difficult they are to maintain.

At the time of the 2000-2001 survey, pool operators were asked whether or not they held a copy of the 1996 Guidelines, with most operators stating they had received a copy in previous years from their local council or inspecting officers from the Mid Western Public Health Unit. The main emphasis was placed on chlorine and $\mathrm{pH}$ levels as these two parameters are seen to be of greatest risk to public health.

Cyanurate returned the highest overall failure levels. However, if cyanurate levels were low and free chlorine was $>1 \mathrm{mg} / \mathrm{L}$, there was no public health risk, therefore there was no need to place a closing order on the pool.

\section{TABLE 4}

OVERALL FAILURE RATE FOR ALL POOLS, BROKEN DOWN BY CHEMICAL PARAMETER IN 2000-2001 COMPAREDTO 1992-1993

\begin{tabular}{|lcc|}
\hline $\begin{array}{l}\text { Chemical } \\
\text { Parameter }\end{array}$ & $\begin{array}{c}\text { Failure Rate (\%) } \\
\text { 1992-1993 }\end{array}$ & $\begin{array}{c}\text { Failure Rate (\%) } \\
\text { 2000-2001 }\end{array}$ \\
\hline Free chlorine & 36 & 17 \\
Total chlorine & 12 & 14 \\
Combined chlorine & 2 & 0 \\
pH & 24 & 25 \\
Reserve alkalinity & 26 & 28 \\
Cyanurate & 83 & 68 \\
Overall Failure Rate & 71 & 69 \\
\hline
\end{tabular}

Reserve alkalinity recorded higher levels in both the Olympic pools and $25 \mathrm{~m}$ pools when compared to the 1992-1993 survey. The $\mathrm{pH}$ levels can have a bearing on the disinfecting power of free chlorine, particularly when they are greater than 7.8 as the equilibrium favours the hypochlorite ion rather than more efficient hypochlorous acid species. A pH level of 7.2-7.8 is preferred as it offers a more comfortable environment for swimmers. There was no significant change in $\mathrm{pH}$ levels between the two surveys.

The failure rates for free and total chlorine were relatively low compared to the 1992-1993 survey with both showing a reduction in overall failure rates. Because free chlorine is readily consumed, constant monitoring is required. If free chlorine is not maintained at the required levels, then its effectiveness as a disinfectant can not be guaranteed. ${ }^{2}$ Another factor that led to failure rates in free and total chlorine was not maintaining free and total chlorine greater than $3 \mathrm{mg} / \mathrm{L}$ as required by the 1996 Guidelines when using cyanurate.

Each type of pool seemed to have their problem parameters. Olympic pools had higher levels in both $\mathrm{pH}$ and cyanurate, the 25-metre pools recorded higher levels in reserve alkalinity, and the toddler pools recorded higher levels in both free and total chlorine.

Public swimming pools run by the community in smaller townships returned the highest non-compliance rates with the 1996 Guidelines. A lack of understanding of water chemistry requirements and maintenance seems to be a contributing factor. At the time of the 2000-2001 survey, if a parameter did not meet the requirements of the 1996 Guidelines, the pool operators were made aware of what the failure was; and advice was given on how to adjust the chemicals in the pool so that the parameters would meet the requirements. Requests were made at the time of the survey to have the adjustments made as soon as possible. 


\section{CONCLUSION}

Modest improvements have occurred in some chemical levels for parameters of water quality in swimming pools. Since the introduction of the NSW Department of Health's Public Swimming and Spa Pool Guidelines 1996 greater emphasis has been placed on maintaining disinfection at a level that will assist in the removal of disease-causing organisms.

Pool operators not meeting requirements of the 1996 Guidelines were given on the spot advice to rectify problems identified in the survey. Failures in chemical levels for parameters alone do not necessarily mean a health risk to the public. Where failures were identified, additional factors were considered such as number of bathers, and type and method of disinfection. If the pool was assessed as a public health risk it would be closed until problems were rectified. In this survey, none of the pools required closure.

The Mid Western Public Health Unit will be working with pool operators during the 2001-2002 summer season to ensure that appropriate maintenance and monitoring occurs. With regard to chemical levels for parameters of water quality, an emphasis will be placed on chlorine and $\mathrm{pH}$ levels, as these are considered the greatest risk to public health if not maintained appropriately.

\section{REFERENCES}

1. Hoadley AW and Knight DE. External Otitis Among Swimmers and Nonswimmers. Archives of Environmental Health September 1975; 30: 445-448.

2. NSW Department of Health. Public Swimming and Spa Pool Guidelines 1996. Sydney: NSW Department of Health, 1996. State Health Publication No.(EHF\&B) 960106.

3. Southern Sydney Public Health Unit. Cryptosporidiosis Outbreak in Southern Sydney. Public Health Update February 1995; 2(2).

4. Palintest. The Palintest System-Test Instructions for Pooltest 25. Newcastle upon Tyne: Palintest Ltd, 1998.

5. Palintest. The Palintest System-Test Instructions for Photometer 5000 Pool Test Kit. Newcastle upon Tyne: Palintest Ltd, 1980.

6. Shaw N. Study of Public Swimming Pools and Spa Pools in NSW, 1993. NSW Public Health Bulletin 1994; 5(12): 131-133. 借

\section{DEVELOPMENT OF A CHILD AND YOUTH HEALTH REPORT CARD FOR CENTRAL SYDNEY, 2000}

\section{Belinda O'Sullivan \\ Public Health Officer Training Program \\ NSW Department of Health}

\section{Garth Alperstein and Ajsa Mahmic \\ Division of Population Health \\ Central Sydney Area Health Service}

This article describes how the first Child and Youth Report Card for the Central Sydney Area Health Service (CSAHS) was developed. The purpose of the Report Card is to contribute to the improvement of child and youth health outcomes through supporting service planning by providing regular information on the status of child and youth health in CSAHS to managers, planners, health professionals and other relevant stakeholders in child and youth health.

\section{BACKGROUND}

Over the past decade there has been an increased focus nationally and internationally on useful ways of monitoring child and youth health for the purpose of informing service planning. ${ }^{1-3}$ The emphasis is moving from using information that is available and easy to collect for routine reporting, to information that is more helpful to service planning and service delivery, and for monitoring health outcomes.

The Strategic Plan Health Gain for Children and Youth in Central Sydney marked a first attempt in the CSAHS to determine priority issues for children and youth. ${ }^{4}$ It used the Health Goals and Targets for Australian Children and Youth as a basis for the plan. 'High priority' health issues were ascertained by analysing information on:

- prevalence

- severity of a condition

- community concern for the issue

- efficacy of available interventions.

\section{METHODS}

To establish the Report Card, it was necessary to determine the information that would be useful to include. In order to build on the work undertaken for the Strategic Plan-and to improve our understanding of indicators-Mahmic, Alperstein and Ward undertook a survey of 36 national and international 'experts' in child and youth health (unpublished data). 'Experts' were health professionals who had expertise in both child health and public health. The response rate was 72 per cent (26 respondents).

A questionnaire requested the experts to rate the importance of monitoring 135 health, social and educational issues for the population as a whole and for the socioeconomically disadvantaged, and also to rate how frequently the data should be collected (annually or every five years, etc.). The list of 135 issues was developed from the Strategic Plan as well as from the national and international literature on the monitoring of child health and indicators. The responses were analysed for agreement by the experts at two levels of concordance- -75 per cent and 90 per 